IJOTL -TL, Vol. 2, No. 3, September 2017

p ISSN: 2502 2326; e ISSN: 2502 8278

Http://ijolt1.pusatbahasa.or.id; Email: ijolt1@gmail.com

Center of Language and Cultural Studies, Surakarta, Indonesia

Mahsa, Masithah; Setiawan, Budi \& Rohmadi, Muhammad. 2017. Strategies to Develop Argumens in

Academic Writing by Students of Graduate Program in Indonesian Language Education

Sebelas Maret University. IJOTL TL (2017), 2(3): 177 190. DOI:10.30957/ijolt1.i2n3.387.

\title{
STRATEGIES TO DEVELOP ARGUMENTS IN ACADEMIC WRITING BY STUDENTS OF GRADUATE PROGRAM IN \\ INDONESIAN LANGUAGE EDUCATION SEBELAS MARET UNIVERSITY
}

\author{
Masithah Mahsa ${ }^{1}$ \\ Budhi Setiawan $^{2}$ \& Muhammad Rohmadi ${ }^{3}$ \\ Graduate Program of Indonesian Language Education \\ Sebelas Maret University \\ Jl. Ir. Sutami 36 A Kentingan Surakarta, Central Java, Indonesia \\ Email: ${ }^{1}$ masithahmahsa@yahoo.co.id, ${ }^{2}$ buset74@yahoo.com, \\ rohmadi_dbe@yahoo.com
}

\begin{abstract}
There is a relationship between pattern of arguments in an academic writing and obstacles faced in writing process. This study aims to figure out the strategies to develop arguments in writing a scientific article used by the students of Graduate Program in Indonesia Language Education Sebelas Maret University. The study focuses on obstacles in writing the scientific article, and the strategies how students overcome the problem. This study is a qualitative descriptive research. The instruments were documents and interview sheet that was delivered to the author of the article. In collecting the data, the researcher used purposive sampling technique. The researcher used interactive analysis technique in order to analysis the content of the data. Findings of this study showed that there were two obstacles and solution in arranging the arguments, they were internal and external aspect.
\end{abstract}

Keywords: arguments, academic writing, obstacles, solution

DOI:10.30957/ijolt1.i2n3.387.

\section{INTRODUCTION}

It is true that an academician is demanded to express his/her idea in a form of academic writing. In order to write an academic writing, it is necessary to master the concepts and material well. Before writing the article, the author should fully guarantee that the article can be scientifically accounted for. It is proved by how the author deliver the idea shown from the quality of the arguments in it. So it is important to comprehend the matter of the urgency that will be appointed before beginning to write the article, therefore it is possible to deeply and accurately elaborate the concept. It will be an interesting academic writing if it consists of the most recent concepts, methods, findings, and conclusions. 
IJOTL TL, Vol. 2, No. 3, September 2017

p ISSN: 2502 2326; e-ISSN: 2502 8278

Http://ijolt1.pusatbahasa.or.id; Email: ijolt1@gmail.com

Center of Language and Cultural Studies, Surakarta, Indonesia

Mahsa, Masithah; Setiawan, Budi \& Rohmadi, Muhammad. 2017. Strategies to Develop Argumens in

Academic Writing by Students of Graduate Program in Indonesian Language Education

Sebelas Maret University. IJOTL TL (2017), 2(3): 177 190. DOI:10.30957/ijolt1.i2n3.387.

Writing a scientific article taken from a thesis does not simply shorthen the report of research finding but it is more like taking important parts, summarizing and restating the knowledge from research finding in a way of communicative language. An author won't be able to write a scientific article if he just explains the theory and the data without criticizing and analysis. However, there are so many arguments stated so commonly and not holistically therefore the article becomes an uninteresting one. But actually the case is the academicians of Indonesian are demanded to publish their scientific article to international scale (Law of The ministry research and technology higher education No. 44 year 2015). The fact shows that Indonesia takes the lowest amount of publication at $53^{\text {th }}$ position comparing to the neighboring countries such as Malaysia, Singapore, and Thailand (Scimagojr.com). In line with this fact, Setyaningsih (2016:1) stated that journal article has a relation to the low of the participation from the academicians of Indonesia. Based on that argument, it can be concluded that writing scientific article is not entrenched yet in Indonesia.

Students as academicians are demanded to create high quality works for instance through scientific article. In reality, it is found that many students are able to be a great orator, a good motivator or speaker but sadly they cannot create a great written works. They just can express their briliant ideas orally (Rahmiati, 2014). They propose some reasons and obstacles such as laziness, difficult to focus, etc. Those problems surely can be solved if they have a will to try.

The quality of a scientific article is shown by the elaboration of the arguments stated in the writing. The more powerful arguments are elaborated, the less obstacles are faced in writing process, and vice versa. It can be concluded that the obstacle affects the strength of the argument. Based on that conclusion, the objective of this study is strategy used by the students of Postgraduate Program of Bahasa Indonesia Education, Sebelas Maret University, on arranging the argument in writing a scientific article.

\section{REVIEW OF LITERATURE}

\subsection{Argumentation Paragraph}

\subsubsection{Definition}

Wijayanti (2013:122) said argumentation paragraph is a paragraph that contains proof or discussion on the author's opinion about a matter. In addition, Keraf (2001:3) says that argumentation is a form of rhetoric that seeks to influence attitude and opinions of others that they believe and act in accordance with what is desired by the author. Argumentation is set to present evidence in stating the attitude or opinion of a thing. In the argumentation paragraph the author convinces the reader by including evidence, examples, or reasons. Rohmadi et al (2014:87) admit argument aims to influence or convince readers to declare their consent.

Argumentative writing is "vital to equip learners for success in the twenty first century" (Richards dalam Xargia, 2016:1). Deane (in Pritasari, 2016:2) said that argumentation reflects each individual's thinking ability. In summary, argumentative paragraph contains statements, ideas and opinions accompanied by logical evidence. 
IJOTL $-T L$, Vol. 2, No. 3, September 2017

p ISSN: 2502 2326; e -ISSN: 2502 8278

Http://ijolt1.pusatbahasa.or.id; Email: ijolt1@gmail.com

Center of Language and Cultural Studies, Surakarta, Indonesia

Mahsa, Masithah; Setiawan, Budi \& Rohmadi, Muhammad. 2017. Strategies to Develop Argumens in

Academic Writing by Students of Graduate Program in Indonesian Language Education

Sebelas Maret University. IJOTL TL (2017), 2(3): 177 190. DOI:10.30957/ijolt1.i2n3.387.

Argumentation plays an important role in developing a pattern of critical thinking and adding the understanding.

\subsubsection{Element of Toulmin Models Argumentation}

The ability to explain and justify from statements is part of the ability to create arguments (Saracaloglu in Pritasari, 2016:3). Meanwhile, Toulmin dkk (1979:25-26) divides the argument into six categories: (1) claims stating the writer's position, (2) ground to prove the argument, (3) warrants that serve as a bridge between claims and ground, (4) backing in the form of a statement that serves to support warrants, (5) modals are statements that limit the strength of arguments or propose condition in the correct argument, and (7) rebuttals is other options if modals have not been received. See Figure 1.

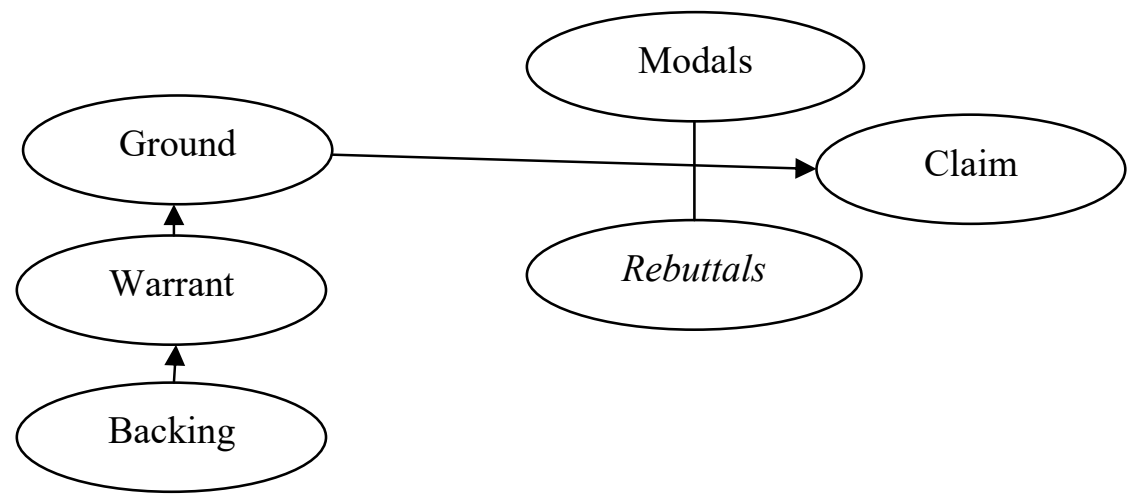

Figure 1. Elements of Argumentation Toulmin Models

\subsection{Scientific Article Writing}

\subsubsection{Definition of Writing}

Writing is a language skill that used to communicate indirectly with others (Tarigan, 2008: 3). This is in line with Hariwijaya (2011:19) explained in the process of writing we can explore fresh ideas that can be poured in writing. The idea can come from experience, imagination, from rationality or reasonable thinking. Based on that, it can be concluded that writing is an activity of delivering messages (ideas, feelings, and information) in writing to others that function as a form of verbal communication. It involves the author as a messenger, message or content, channel or writing medium, and reader as the recipient of the message.

\subsubsection{Purpose and Functions of Writing}

The function of writing is a communication indirect. Writing is very important for education because it makes easier for students to think and also help someone to think critically. It can facilitate a person to feel and enjoy relationships, deepen the perceptive person, problem solving, arrange the sequence for experience. Writing can help a person explain his thoughts (Tarigan, 2008:22). Furthermore, Akhaidah (2004:1-2) said that the implementation of writing activities, namely: (1) recognize the ability and potential of 
IJOTL -TL, Vol. 2, No. 3, September 2017

p ISSN: 2502 2326; e-ISSN: 2502 8278

Http://ijolt1.pusatbahasa.or.id; Email: ijolt1@gmail.com

Center of Language and Cultural Studies, Surakarta, Indonesia

Mahsa, Masithah; Setiawan, Budi \& Rohmadi, Muhammad. 2017. Strategies to Develop Argumens in

Academic Writing by Students of Graduate Program in Indonesian Language Education

Sebelas Maret University. IJOTL TL (2017), 2(3): 177 190. DOI:10.30957/ijolt1.i2n3.387.

self, (2) develop some ideas, (3) broaden the horizons, (4) can explain the problems (5) able to review and rate ideas themselves more objectively, (6) easier problem solving, and (7) encouraging self-learning actively.

Based on this, it can be concluded that writing can generate new ideas and can be used as a problem solving tool. By writing a person can also absorb and process more information so that insight and knowledge increases.

\subsubsection{Definition of Scientific Articles}

Wibowo (2013:1) said a scientific article is a special writing written back from a research result. Correspondingly, Tanjung (2013:7) stated a scientific article is a paper designed to be published in a journal or a collection of articles written in scientific ordinances and following scientific or agreed guidelines or scientific conventions.

Based on that, it can be concluded that the scientific article is a special paper that comes from research and non-research that has fulfilled the scientific rules and published based on the rules of the media that publish it, without ignore the principles of structure, systematic, and the content of the article.

\section{METHODS}

This study was a qualitative descriptive research. Samples of this study were three students Postgraduate Program of Bahasa Indonesia Education, Sebelas Maret University, they are Artika Bekti Pratiwi (AB), Khairul Anam (KA) dan Khairunnisa $(\mathrm{Kh})$ those were chosen through purposive sampling technique. The resources of the data were the documents, they are students' articles and the script of the interview taken from the students. Interview was also done to the lectures who were the reviewer of some journal articles. Validity of data in this research using triangulation of source and method. Triangulation of sources is the technique of examining the validity of data analysis results through interviews with different informants or sources, but still discuss the same issues. Meanwhile, triangulation method is a technique or method of collecting different data (Sugiyono, 2008:242). Technical analysis of data in this study using technical interactive analysis consisting of three stages of data reduction, data presentation and conclusion.

\section{FINDINGS AND DISCUSSION}

\subsection{The Pattern of Argumentation in Writing Scientific Article}

The pattern of argumentation on AB's article entitled "Keefektifan Metode Kotak Kata terhadap Kemampuan Membaca Cerita Anak Ditinjau dari Motivasi Belajar Bahasa Indonesia Pada Siswa Kelas VII SMP Negeri Kabupaten Klaten (The Effectiveness of Box Word Method toward the Ability of Reading Child's Story Viewed from the Motivation to Learn Bahasa Indonesia of Grade VII Students in Klaten Regency)" consisted of four elements such as claim, ground, warrant dan backing. It is proven by the result as follow.

(C) "Box Word Method is effective to be implemented in learning process of reading child's story, because by applying this method, students did 
IJOTL TL, Vol. 2, No. 3, September 2017

p ISSN: 2502 2326; e ISSN: 2502 8278

Http://ijolt1.pusatbahasa.or.id; Email: ijolt1@gmail.com

Center of Language and Cultural Studies, Surakarta, Indonesia

Mahsa, Masithah; Setiawan, Budi \& Rohmadi, Muhammad. 2017. Strategies to Develop Argumens in

Academic Writing by Students of Graduate Program in Indonesian Language Education

Sebelas Maret University. IJOTL TL (2017), 2(3): 177 190. DOI:10.30957/ijoltl.i2n3.387.

not just have to read the text but also comprehending so that they could answer the questions in students' exercise sheet." (G) "FA=5.69> $F 0.05 ; 1,68=3.98$, so $H 0 A$ be rejected, $F B=16.59>F 0.05 ; 1,68=$ 3.98 , so $H O B$ be rejected, and $F A B=9.73>F 0.05 ; 1,68=3.98$, so HO $A B$ be rejected." (W) "Students' capability in reading child's story who were taught through Box Word Method were better than the ones who taught through contextual method, students' capability in reading child's story who had higher motivation in learning bahasa Indonesia was better than the one who had lower motivation, and there was correlation between learning method and students' motivation in learning bahasa Indonesia toward students' ability in reading child's story." (B) "In line with the research that was conducted by Alshumaimeri (2011: 194) entitled The Effects of Reading Method on the Comprehension Performance of Saudi EFL Students. Learning of reading comprehension needs the appropriate method so that the students are able to comprehend a text. In Alshumaimeri's research, it was found that oral reading had positive effect and was reputed more helpful for students to memorize and focus. Innovation took place on the learning method in reading. It was Box Word Method. The method of oral reading emphasized on the memorizing and focusing ability, while Box Word Method emphasized on the accuracy and stimulating students to think effectively."

The analysis above shows that this article included four elements, they are claim, ground in a form of the data of test result, warrant and backing those were the result of previous research. It could be stated that the argument was strong and could be proven because it attached the main elements and the elements that supported the argument.

The pattern of argumentation on KA's article entitled 'Kajian Dekontruksionisme dan Pemakaian Bahasa Novel Tak Sempurna Karya Fahd Djibran dan Bondan Prakoso \& Fade2Black Ditinjau dari Nilai Pendidikan Karakter (A Study of Deconstructionism and Language Usage in Novel Tak Sempurna by Fahd Djibran dan Bondan Prakoso \& Fade2Black Viewed from the Value of Educational Characters)" consisted of four elements such as claim, ground, warrant dan backing. It is proven by the result as follow.

(C) Language style of novel Tak Sempurna do not adopt the language style of conventional novel, but it is more similar to the style of drama performance or even movie and science-fiction. There is difference between the school that was wanted by character Rama then it was called as "dream school" and school that Rama took his education that then it was called as"real school". The value of educational character is the important thing for people's life to raise and build the human dignity so that they are able to be a civil society. (G) Interlude in this novel Tak Sempurna is like an advertisement of energizing drink in a soccer match. The interlude will attract the readers more deeply into the story and after 
IJOTL TL, Vol. 2, No. 3, September 2017

p ISSN: 2502 2326; e ISSN: 2502 8278

Http://ijolt1.pusatbahasa.or.id; Email: ijolt1@gmail.com

Center of Language and Cultural Studies, Surakarta, Indonesia

Mahsa, Masithah; Setiawan, Budi \& Rohmadi, Muhammad. 2017. Strategies to Develop Argumens in

Academic Writing by Students of Graduate Program in Indonesian Language Education

Sebelas Maret University. IJOTL TL (2017), 2(3): 177 190. DOI:10.30957/ijolt1.i2n3.387.

finishing of reading this novel, the readers are ready to be the agent of change from the doctrine that is conveyed by the authors' prior idea. School as the symbol of "Imperfection" has something different from the other common ones and as the illustration of school in general that is dreamt by all people and Rama in this story. While "Imperfection" as the symbol of the school that Rama wanted to tell is the invers of the illustration of the school in general that has been actually explained. The illustration of "Imperfection" as a symbol that was assosiated by the school that Rama wanted to tell to. (W) The structure of the novel combines several styles, including fiction diary, letter and poem, and uses the other style and device to explore the post modern anxiety from the authority of textual narative. Value is everything about good and bad, that has chharacteristics or something important and useful for humanity. (B) "The result of Reggina Rudaityte's research shows that there are some modern deconstruction in the novel Possesion by A. S. Byatt they are structure and plot of the novel. Reggina Rudaityte stated that the author plays with time, keeps moving between past and present."

Ground in that argument was fact so that the statement of the author's position could be formed. Then, the author related ground and claim to a guarantee warrant. To maintain warrant the author completed them with backing that was a result of previous research. Based on the analysis above and Toulmin's opinion, it could be concluded that the pattern of author's argumentation was strong because it included the main elements those were claim, ground and warrant and supporting element that was backing.

The pattern of argumentation on Kh's article entitled "Hubungan antara Penguasaan Piranti Kohesi dan Koherensi dan Motivasi Berprestasi dengan Keterampilan Menulis Eksposisi (Survei Pada Siswa Kelas X SMK Negeri Se-Kota Purwokerto) (Correlation between Cohesion and Coherence Instruments Mastery and Motivation of Achievement to the Skill of Writing Exposition Text (Based on the Survey to the Grade X Students of Public Vocational Senior High School in Purwokerto))" consisted of four elements such as claim, ground, warrant dan backing. It is proven by the result as follow.

(C) "There is a positive relation between cohesion and coherence instruments mastery and skill of writing exposition text, there is a positive relation between motivation of achievement and skill of writing exposition text, and there is positive relation between cohesion and coherence instruments mastery and motivation of achievement with skill of writing exposition text." (G) "Based on the test result, it is shown that the strength of the relationship between cohesion and coherence instruments mastery and skill of writing exposition text is at 18.31 point that is higher 1.66 point than $t_{t a b}$. The strength of the relation between motivation of achievement and skill of writing exposition text is at 5.39 that is higher 1.66 point tan $t_{\text {tab }}$ and based on (Ry.12) it is at 0.87 point 
IJOTL TL, Vol. 2, No. 3, September 2017

p ISSN: 2502 2326; e ISSN: 2502 8278

Http://ijolt1.pusatbahasa.or.id; Email: ijolt1@gmail.com

Center of Language and Cultural Studies, Surakarta, Indonesia

Mahsa, Masithah; Setiawan, Budi \& Rohmadi, Muhammad. 2017. Strategies to Develop Argumens in

Academic Writing by Students of Graduate Program in Indonesian Language Education

Sebelas Maret University. IJOTL TL (2017), 2(3): 177 190. DOI:10.30957/ijolt1.i2n3.387.

then it is obtained the coefficient of determination at 0.7569. It means that $75.69 \%$ of all varieties show the tendency of writing skill of exposition text can be explained by cohesion and coherence instruments mastery and motivation of achievement through regression $\hat{Y}=-8,85+2,50 X 1+0,15$ X2." (W) "Cohesion and coherence instruments mastery contributes 73.96 point to skill of writing exposition text, motivation of achievement contributes $51.84 \%$ to skill of writing exposition text and cohesion and coherence instruments mastery also contributes $75.69 \%$ to skill of writing exposition text." (B) "Based on Cihak and Castle's research (2011) it was stated that improvement of the writing quality could be seen after the student was given the intervention in writing. For two students who were separated, the biggest development between pretest and posttest in paragraph structure, that was writing an esay that was well-organized and the topic developed well. The existence of introductory sentences and central ideas were expanded and coherence with the use of sentence in detail. The utterance transitions and closure sentence were showed as well. So that it could be concluded that the cohesion and coherence instruments mastery was the aspect that contributes the most to skill of writing exposition text. And then, the research that was conducted by Beydogan (2011) proved that by implementing the appropriate learning method might increase stundents' motivation of achievement in writing exposition in a control group or experiment group.

Claim above showed that how the author's position in the article. In this article, the data that was explained was the test result. Then, the author guaranteed that to make sure whether ground and claim were relevant or not. It would not be strong without the support (backing), in this case backing that was explained was the result of relevant study. Based on the identification above, it could be concluded that the author's argument was strong because attaching both main and supporting elements.

\subsection{Problems and Solution to Develop the Arguments}

Obstacles to formulate arguments in the writing of scientific articles and solutions to overcome them can be seen based on the interviews of the three authors of the article and two lecturers who are practitioners of journal articles. These barriers are related to the pattern of arguments produced by each author. Generally the main obstacle experienced by the informant is feeling lazy. This is evidenced from the results of the following interviews.

Kh: "The laziness to read books and find information, confused want to start from where it is difficult to bring up a problem. Usually I am adasati by making work planning, so when the sense of lazy arrived I immediately see the list to do that has been made." (Excerpt 1)

Based on the above interviews it can be seen that the obstacles experienced by informants $\mathrm{Kh}$ is lazy to read books and seek information. However, Kh has a solution 
IJOTL TL, Vol. 2, No. 3, September 2017

p ISSN: 2502 2326; e ISSN: 2502 8278

Http://ijolt1.pusatbahasa.or.id; Email: ijolt1@.gmail.com

Center of Language and Cultural Studies, Surakarta, Indonesia

Mahsa, Masithah; Setiawan, Budi \& Rohmadi, Muhammad. 2017. Strategies to Develop Argumens in

Academic Writing by Students of Graduate Program in Indonesian Language Education

Sebelas Maret University. IJOTL TL (2017), 2(3): 177 190. DOI:10.30957/ijolt1.i2n3.387.

to overcome that is by making work planning so that when feeling lazy approach, $\mathrm{Kh}$ directly see the plan work.

In the process of writing, some informants experience errors in the argument, including errors in reducting data with the formulation of the problem, mistakes in reducing the data and errors in the systematics of writing and linguistic. This is evidenced from the interviews of the following informants KA.

KA: "Using less appropriate procedures so as not to solve the problem appropriately. The solution I re-read my article article while looking for the right procedure to solve the problems contained in the article. Not to mention the busy schedule of activities, inadequate references and lack of friends discussing” (Excerpt 2)

Based on this, it can be said that the informant KA had a mistake in reducing the data. This can happen because of the lack of experience in writing scientific articles, density of author activity, inadequate reference and no friends to discuss. However, KA informant overcames it by re-reading the article. In contrast to KA, the informant $\mathrm{AB}$ had difficulty in balancing the data with the formulation of the problem. This can happen if the arguments presented are too convoluted. This is evidenced from the results of the following interviews.

AB: "Usually because of the preoccupation of writing, sometimes my writing is too widespread and deviated from the problem formulation.

Well, as much as possible using effective sentences and reread each sub chapter. But if it stuck, I usually discuss with friends or lecturers." (Excerpt 3)

Based on the results of the interview, it can be seen that the barrier of the informant $\mathrm{AB}$ is the difficulty in connecting the data with the formulation of the problem. This means that it is difficult for $A B$ to focus on writing. However, AB trick it with as much as possible using effective sentences and reread each sub chapter and discuss with people who understand the issues of the article both friends and lecturers.

Informant MR as a lecturer and journal practitioner said that the obstacles that usually appear in the writing of scientific articles that are less reading books and less seeking information. This is proved from the result of the following interview.

MR: "Students are now lazy to read and less seeking information. For that, students should participate in literacy programs of information and knowledge, for example in the library or held in the faculty. In UNS itself there is a program called educational development of education-based information and knowledge. It starts from how to browse these articles in both national accredited journals, internationally accredited journals as well as e-books and everything covered in them. Well, it should be applied to instill habits in the students so they are trained to see those aspects. That way they know what their journals are, their metadata structure, their characteristics, their spelling order, their style so that 
IJOTL TL, Vol. 2, No. 3, September 2017

p ISSN: 2502 2326; e ISSN: 2502 8278

Http://ijolt1.pusatbahasa.or.id; Email: ijolt1@gmail.com

Center of Language and Cultural Studies, Surakarta, Indonesia

Mahsa, Masithah; Setiawan, Budi \& Rohmadi, Muhammad. 2017. Strategies to Develop Argumens in

Academic Writing by Students of Graduate Program in Indonesian Language Education

Sebelas Maret University. IJOTL TL (2017), 2(3): 177 190. DOI:10.30957/ijolt1.i2n3.387.

they can follow the ATM concept of observing, imitating, and modifying. Well from there create articles that they are not packed on the same concept but have what innovation they have imitated. (Excerpt 4)

Based on this, it can be concluded that the obstacles that usually appear in preparing the argument on writing a scientific article that is lazy to read and less seeking information. However, MR provides a solution to overcome these obstacles that encourage students to participate in literacy programs held by university. For example, utilizing campus library facilities and programs. In UNS, there is a journal education development program that aims to instill reading habits on the students. So that students are able to create new articles that have innovation.

Reflecting with the previous, KS informant who is also a lecturer and practitioner of the journal mentioned that the obstacle to arrange argument in writing of scientific article consist of lazy reading, lack of experience in writing and lack of reference. This is evidenced from the results of the following interviews.

KS: "Many things become obstacles in writing journal articles, both internal and external. For internal, the obstacles related to the reference. This reference, how? Still confused. The first thing to do is to find all the free online referrals the easiest is google scholar, the list in the national library then, science direct and science letter as well as all sites that offer references and e-books. So the first thing we do is find sources to enrich the objects we examine. After we get the references, then we sort out the relevance to our research, for example you research about the language as much as possible get a full paper reference. After that, check out the list of libraries and browse. Of course this makes it easier for us to find relevant references. Furthermore, the second obstacle is lack of experience and feeling lazy. This can be overcome when students diligently read the journal. Well that's why in UNS there is a minimal reference policy for postgraduate program that are so many journals. It is one of the efforts to make students familiar with journals. Especially now that a graduate student must be an international journal, inevitably have to write an English-language journal and it is very good in the future. Students do not merely write, they must be publications and percentages. So, writingnya good speakingnya also good. That's what will give a plus. Perhaps other universities do not implement it but in UNS requires that postgraduate competencies really have the ability to both speak academic and academic writing. Furthermore, feeling lazy. If we are lazy how to develop the proposal was not so-so, changing the topic is the characteristics of lazy students. So should focus on researching what, we are looking for references as much as possible then we synthesize into a steady title, when the references have been much then when discussed in our discussion more easily analyze it by mengcombine relevant journals. So our research novelty will look there if many read the journal if lazy hard later in chapter four." (Excerpt 5) 
IJOTL TL, Vol. 2, No. 3, September 2017

p ISSN: 2502 2326; e-ISSN: 2502 8278

Http://ijolt1.pusatbahasa.or.id; Email: ijolt1@gmail.com

Center of Language and Cultural Studies, Surakarta, Indonesia

Mahsa, Masithah; Setiawan, Budi \& Rohmadi, Muhammad. 2017. Strategies to Develop Argumens in

Academic Writing by Students of Graduate Program in Indonesian Language Education

Sebelas Maret University. IJOTL TL (2017), 2(3): 177 190. DOI:10.30957/ijolt1.i2n3.387.

Based on this, it can be concluded that the obstacle to make an argument in writing a scientific article is lack of reference and feeling lazy. However, informant KS provides solutions to overcome these obstacles. Obstacles to lack of reference are overcome by reading many free online references temporarily to overcome the sense of laziness, KS recommends the author should focus with what is being studied so that the spirit of searching relevant references to make it easier to analyze the problems in the article.

The resulting argumentation patterns in drawing arguments in scientific articles are closely related to the constraints of each author. If the obstacles that the writer has a bit, certainly the argument produced strong. Conversely, if the obstacles that arise in composing arguments are sufficiently numerous, then the resulting argument also tends to be simple. A related study of arguments was previously conducted by Wulandari et al (2016) entitled "Peningkatan Motivasi dengan Kemampuan Menulis Argumentasi dengan Model Pembelajaran Think Talk Write dan Media Audiovisual Pada Siswa Sekolah Menengah Atas (Motivation Improvement with Argumentation Writing Skill with Think Talk Write and Audiovisual Media Learning Model in High School Students)" which concluded that there was an increase in students' motivation in writing arguments with TTW and Media models Audio visual. The confluence of the study with this research is equally to examine about writing argumentation. While the difference lies in the object of the study. If the research examines high school students, then this study examines Graduate students.

Based on the above findings, the argumentation patterns of the three authors are strongly categorized because they include the main elements and supporting elements. As for the obstacles, there are two barriers found in this study that are internal barriers and external barriers. Internal barriers are obstacles that arise from within the author. While external barriers are barriers that originate outside the author's self. Internal obstacles that arise such as (1) feeling lazy, (2) confused to start, (3) density of activities, (4) lack of reading books and writing experience, and (5) difficult to focus. Meanwhile, external barriers include (1) inadequate information and (2) no friends discussing.

The above obstacles are mentioned inhibiting the development of strong arguments in the writing of scientific articles. Lazyness is a common barrier to formulate arguments. This can happen because of low motivation in writing the article. Confused to start from where, this happens if the author has an exaggerated fear of articles generated due to lack of confidence in writing. Dense activity also affects the creation of a strong argument in the writing of scientific articles, because of fatigue with activity so often delay in writing. Related to the lack of reading books and writing experience have an effect on the resulting writings such as easy to run out of ideas as well as the language and content displayed are vulnerable to plagiarism. Further difficult to focus, this can happen if too much thought or too wide in the argument exposure so as not to fit the problem formulation. In addition to the internal constraints above, there are also external barriers that are inadequate information both in terms of literature and data derived from direct sources. Related to the absence of friends discuss. 
IJOTL TL, Vol. 2, No. 3, September 2017

p ISSN: 2502 2326; e ISSN: 2502 8278

Http://ijolt1.pusatbahasa.or.id; Email: ijolt1@gmail.com

Center of Language and Cultural Studies, Surakarta, Indonesia

Mahsa, Masithah; Setiawan, Budi \& Rohmadi, Muhammad. 2017. Strategies to Develop Argumens in

Academic Writing by Students of Graduate Program in Indonesian Language Education

Sebelas Maret University. IJOTL TL (2017), 2(3): 177 190. DOI:10.30957/ijolt1.i2n3.387.

This is very necessary because if we run out of energy in exposing the writing of course we need a friend to discuss. It aims to complete the data if the information we need is inadequate.

The research related to obstacles in writing has been done previously by Rahmiati (2014) entitled "Analisis Kendala Internal Mahasiswa dalam Menulis Karya Ilmiah (Analysis of Student Internal Constraints in Writing Scientific Works)" which summed up the internal constraints in writing scientific papers namely feeling lazy, not mood and lack of confidence, lack of understanding of the concept of scientific papers , difficulty in finding ideas, less interested in writing activities and difficulty getting started. The equation of this research with this research is equally analyze about obstacle in writing. While the difference lies in the object under study. If the research examines the fourth semester student of UIN Alauddin Makassar, this research examines the graduate students of Indonesian Language Education.

Problems will not be over if people do not want to try. The problematics of composing arguments in writing both internally and externally also have solutions. These constraints are addressed by informants in various ways. Kh chose to make a work plan or list to do to cope with his sense of laziness. It can also be overcome by generating self-motivation and then changing lifestyles. It is also justified by KS that the sense of laziness can be lost if we focus on what we do. Meanwhile, the informant KA chose to reread his article and look for appropriate procedures if the procedures used were not appropriate. For obstacles in the form of density of activity, can actually be overcome by we set the schedule and take time off. This is certainly very helpful in the completion of our article.

Obstacles in the form of lack of adequate reference can be overcome by reading as many books and discussing with others. In addition, it can also take advantage of facilities and programs in the library, as has been told by the informant MR students must participate in literacy program knowledge in the library of UNS. This aims to introduce how the ins and outs of journals both in terms of structure and others. Thus, students are familiar with it. The next thing happens of course the student is able to create a quality article by exposing a strong argument.

In composing arguments in scientific articles, sometimes we experience impasse or run out of energy in exposing it. It is better if a writer silences his writings temporarily while digging as much information to complete the data needs. References can be searched anywhere. One of the easiest is online media. This is justified by informant KS who mentions to overcome the lack of reference, the first thing to do is look for a free online reference, be it a journal or e-book. The more we read the references, the more vocabulary and knowledge we get. This certainly has an impact on the arguments produced in scientific articles.

Another obstacle of writing that is too widespread experienced by informant AB. However, $\mathrm{AB}$ as much as possible to use effective sentences and reread each subchapter so that writing continues to focus on the formulation of the problem. It is AB's way to solve its problems in constructing arguments. A handful of facts above show that many problems experienced by students in making arguments. It should be handled, 
IJOTL $-T L$, Vol. 2, No. 3, September 2017

p ISSN: 2502 2326; e-ISSN: 2502 8278

Http://ijolt1.pusatbahasa.or.id; Email: ijolt1@gmail.com

Center of Language and Cultural Studies, Surakarta, Indonesia

Mahsa, Masithah; Setiawan, Budi \& Rohmadi, Muhammad. 2017. Strategies to Develop Argumens in

Academic Writing by Students of Graduate Program in Indonesian Language Education

Sebelas Maret University. IJOTL TL (2017), 2(3): 177 190. DOI:10.30957/ijolt1.i2n3.387.

both from students themselves and educators. However, apart from that all, if we have a high motivation to write, of course we will prepare the plan carefully both in terms of concepts and methods. Certainly, the obstacles that arise can be minimized and even addressed properly and appropriately.

\section{CONCLUSION}

The resulting argumentation patterns in drawing arguments in scientific articles are closely related to the constraints of each author. Based on the results of the above research can be concluded obstacles to make arguments in the writing of scientific articles of the students of the Indonesian Language Education The Postgraduate Program of UNS consists of two internal constraints and external obstacles. Internal barriers are; (4) lack of reading and writing experience, and (5) difficulty in focusing so as to create a sense of boredom. Meanwhile, external barriers include (1) inadequate information and (2) no friends discussing. However, these obstacles can be overcome by making work planning, re-reading the article, take time off, discuss with friends and supervisors, dig as much information and prepare planning carefully both in concept and methodology.

\section{REFERENCES}

Akhdiah, Sabarti. (2004). Pembinaan Kemampuan Menulis Bahasa Indonesia. Jakarta: Erlangga

Anam, Khairul. (2016). Kajian Dekontruksionisme dan Pemakaian Bahasa Novel Tak Sempurna Karya Fahd Djibran dan Bondan Prakoso \& Fade2Black Ditinjau dari Nilai Pendidikan Karakter. Surakarta: UNS

Dikutip dari http://www.scimagojr.com/ countryrank.php

Hariwijaya N dan Triton. (2011). Pedoman Penulisan Ilmiah Skripsi dan Tesis. Yogyakarta: ORYZA

Kementrian Riset Teknologi dan Pendidikan Tinggi. (2015). Peraturan Menristek Dikti tentang standar Nasional Pendidikan Tinggi (Permenristek Dikti No 44 Tahun 2015). Jakarta: Penulis.

Keraf, Gorys. (2001). Argumentasi dan Narasi Komposisi Lanjutan III. Jakarta: PT. Gramedia Pustaka Utama

Khairunnisa. (2015). Hubungan antara Penguasaan Piranti Kohesi dan Koherensi dan Motivasi Berprestasi dengan Keterampilan Menulis Eksposisi (Survei Pada Siswa Kelas X SMK Negeri Se-Kota Purwokerto). Surakarta: UNS

Pratiwi, Artika Bekti. (2016). Keefektifan Metode Kotak Kata terhadap Kemampuan Membaca Cerita Anak Ditinjau dari Motivasi Belajar Bahasa Indonesia Pada Siswa Kelas VII SMP Negeri Kabupaten Klaten. Surakarta: UNS 
IJOTL $-T L$, Vol. 2, No. 3, September 2017

p ISSN: 2502 2326; e-ISSN: 2502 8278

Http://ijolt1.pusatbahasa.or.id; Email: ijolt1@gmail.com

Center of Language and Cultural Studies, Surakarta, Indonesia

Mahsa, Masithah; Setiawan, Budi \& Rohmadi, Muhammad. 2017. Strategies to Develop Argumens in

Academic Writing by Students of Graduate Program in Indonesian Language Education Sebelas Maret University. IJOTL TL (2017), 2(3): 177 190. DOI:10.30957/ijolt1.i2n3.387.

Pritasari, Ade Cyntia., Sri Dwiastuti, Riezky Maya Probosari. (2016). "Peningkatan Kemampuan Argumentasi melalui Penerapan Model Problem Based Learning pada Siswa Kelas X MIA 1 SMA Batik 2 Surakarta Tahun Pelajaran 2014/2015". Jurnal Pendidikan Biologi Volume 8, Nomor 1 Februari, 2016 Halaman 1-7.

Rahmiati. (2014). Analisis Kendala Internal Mahasiswa Dalam Menulis Karya Ilmiah. Jurnal Al-daulah Vol. 3/ No. 2/ Desember 2014/ P 254- 269

Rohmadi, Muhammad dkk. 2014. Belajar Bahasa Indonesia. Surakarta: Cakrawala Media

Setyaningsih, Yuliana. (2016). Manifestasi Argumentasi dalam Penulisan Artikel Jurnal. Disampaikan pada Seminar Nasional PIBSI Ke XXXVII

Sugiyono. (2008). Metode Penelitian Kuantitatif, Kualitatif dan R\&D. Bandung: Alfabeta

Tanjung, Bahdin Nur dan Ardial. (2013). Pedoman Penulisan Karya Ilmiah (Proposal, Skripsi dan Tesis) dan Mempersiapkan Diri Menjadi Penulis Artikel Ilmiah. Jakarta: Kencana Prenada Group

Tarigan, Henry Guntur. (2008). Menulis Sebagai Suatu Keterampilan Berbahasa. Bandung: Angkasa

Toulmin, Stephen., Richard Rieke, Allan Janik. (1979). An Introduction to Reasoning. New York: Macmillan Pusblishers

Wijayanti, dkk. (2013). Bahasa Indonesia: Penulisan dan Penyajian Karya Ilmiah. Depok: PT. Raja Grafindo

Wulandari, Isti., Edy Suryanto, Purwadi. (2016). Peningkatan Motivasi dengan Kemampuan Menulis Argumentasi dengan Model Pembelajaran Think Talk Write dan Media Audiovisual Pada Siswa Sekolah Menengah Atas. BASASTRA Jurnal Penelitian Bahasa, Sastra Indonesia dan Pengajarannya Volume 4 No.2, Oktober 2016 P 99-116

Xargia, Maria. (2016). A comparative analysis of Greek vs. English: Can it be argued that teenagers can argue?. Selected Papers of the 21st International Symposium on Theoretical and Applied Linguistics (ISTAL 21), 839-854 2016 